\title{
The future of subsistence agriculture in the rural community of Uzanu, Edo state, Nigeria
}

\author{
Stephen Onakuse ${ }^{\mathrm{a}}$ \\ Centre for Sustainable Livelihoods, National University of Ireland College, University College Cork
}

Submitted 12 December 2011 / Revised 11 April, 22 May, 16 August and 4 October 2012 / Accepted 1 November 2012 /

Published online 19 December 2012

Citation: Onakuse, S. (2012). The future of subsistence agriculture in the rural community of Uzanu,

Edo state, Nigeria. Journal of Agriculture, Food Systems, and Community Development, 3(1), 61-71.

http://dx.doi.org/10.5304/jafscd.2012.031.021

Copyright (C) 2012 by New Leaf Associates, Inc.

\begin{abstract}
This study examines the current practice of subsistence agriculture in Uzanu, Edo state, Nigeria, and its contribution to the agricultural development and food security of the rural community now and for the future. All the farmers in the region are dependent on subsistence farming based on shifting cultivation and also practice intercropping to an extent. This farming system serves as a livelihood source, providing food, cash, and income as well as serving other social and cultural functions. Subsistence farmers try to manage farming uncertainties based on local knowledge and implemented through community support
\end{abstract}

a Stephen Onakuse is a lecturer and research fellow in the Department of Food Business \& Development, and the Centre for Sustainable Livelihoods, National University of Ireland, University College Cork; +353 21 4903350;

s.onakuse@ucc.ie systems. This article argues that subsistence agricultural practices should be supported as a new approach to both economic and social protection, as it underpins production as well as consumption in resource-poor communities. This study evaluates the role and development of subsistence agricultural development and its adaptations in Uzanu. The results show that rural subsistence agricultural production could be improved if rural farmers had access to training on subsistence farming systems based on indigenous knowledge and skill sets, targeted to enhance and increase farm output.This study concludes that subsistence agriculture is an important element for growth and development in Nigeria despite the low output and income currently generated from it.

\section{Keywords}

food security, poverty alleviation, rural farmers, subsistence agriculture 


\section{Introduction}

We cannot feed over 140 million Nigerians as well as achieving food security by solely depending on boes and cutlass technology.

- Dr. Sayyadi Abba Ruma, Nigeria Minister of Agriculture and Water Resources, 2010

Nigeria depends heavily on the oil industry for its revenues. However, the economy is predominantly agrarian (FSDH Securities Limited, 2011). Despite the small size of subsistence plots and the scattered pattern of production, agriculture continues to play an important role in the rural economy and makes up 40.3 percent of the gross domestic product (GDP), compared with the 15.79 percent made from the sale of from petroleum products (African Development Bank Group [AfDB], 2011; FSDH Securities Limited, 2011). Smallholder lots are defined as those between 0.10 and 5.99 hectares (0.25 to 14.8 acres) (AfDB, 2011). The differences in size of land holding by residents is based on history and attitude toward work. If a person had a grandfather or great-grandfather who occupied a large tract of uninhabited land and worked hard, he maintained absolute ownership rights to the land. Agriculture remains the critical strategic sector that addresses the multiple challenges of achieving broad-based economic growth, creating wealth , generating employment, alleviating poverty, and attaining national food security, as well as promoting Nigeria to among the 20 world leading economies by the year 2020 as set out by the federal government of Nigeria (FSDH Securities Limited, 2011).

Uzanu is a small agrarian community of 8,000 people in the midwestern part of Nigeria, located at latitude 7.2, longitude 6.63333, (DMS) latitude $7^{\circ}$ $12^{\prime} 0^{\prime \prime}$, and (DMS) longitude $6^{\circ} 37^{\prime} 59.99^{\prime \prime}$ at an altitude 396 feet above mean sea level. Uzanu shares a border with the Igbira (Kogi State) in the north, Igiode in the south, Ibie in the west and the Niger river in the east. The residents in the region have extended families within the village and speak a common language (Uneme); the staple foods are cassava (Manihot esculenta), sweet potatoes (Ipomoea batatus) and rice (Oryza sativa) (Onakuse \& Lenihan, 2008).

Subsistence farming and fishing have remained integral parts of agricultural practices in the study area over the years (Onakuse \& Lenihan, 2008). The agriculture is based on the settlement pattern, as the region is prone to regular flooding. Even though market-oriented agriculture provides higher incomes, subsistence agriculture remains prevalent in resource-challenged rural communities (Baiphethi \& Jacobs, 2009). Nevertheless, farmers also sell part of their agricultural produce to provide for family needs (Bryceson, 2000; Ellis, 1993; Redman, 2010).

Subsistence farming is the least understood and arguably most neglected form of agriculture. Some academicians and policymakers have a negative view of this form of agriculture because it is characterized by low use of external inputs and low productivity, and thus is synonymous with backwardness and inefficiency and holds back economic growth and performance (Heidhues \& Brüntrup, 2003). The common characteristics of practitioners of subsistence agriculture are ownership of small lots and/or of non-irrigated cultivable land; sharecroppers or tenants and their households; landless households dependent on livestock activities and/or casual labor; large farming households (usually consisting of extended families); households with high dependency ratios (e.g., adult unable to work); women-headed households; and young women and men living in extended households (International Fund for Agricultural Development [FAD], 2011).

Traditional agricultural practices are synonymous with subsistence agriculture in the region. Both involve traditional agricultural knowledge and practices, which have enabled poor farmers in Uzanu to sustainably use their natural resources and learn to conserve it (Onakuse \& Lenihan, 2008). On the one hand, traditional farming is an indigenous practice of cultivating the land, aimed toward crop and livestock husbandry and holistic management of natural resources, thereby enabling a continual food supply using locally available resources and contributing to self reliance of the community as a whole. Modern agriculture, on the other hand, is similar to traditional farming but 
involves land cultivation at a bigger scale and also rearing of large numbers of livestock.

However, the negative perception of subsistence agriculture has led to inadequate official recognition of its importance in rural development; this is coupled with lack of policies and technical support for sustainable subsistence agricultural development (Heidhues \& Brüntrup, 2003). Some see the small size of most farms as an obstacle to progress, complaining that economies of scale cannot be achieved. Kostov and Lingard (2002) observed that subsistence farming uses resources that could be used in market-oriented farming and other rural sectors and may reduce overall efficiency.

According to Collier (2008), small-scale farming in Africa is not able to meet the challenges of contemporary agricultural development because of the reluctance of peasants to change their mode of production, which is currently ill suited to modern agricultural production. However, underdevelopment of subsistence agriculture outputs are clearly rooted in the traditional agricultural practices that the Uzanu community has been engaged in for years. Families practice agriculture on small plots of land and aim to produce enough to feed their families until the next harvest. Often, the yields are not enough to even feed the family, and this leads to seasonal food shortages. While small family farms continue to dominate the agricultural sector in rural communities, not enough attention is paid to subsistence agriculture. It is therefore not recognized by the government of many developing countries and is considered household production for its own final consumption.

\section{Subsistence Agriculture in Nigeria}

Subsistence agriculture employs about two-thirds of the total labor force in Nigeria and provides a livelihood for the majority of the rural population which may account for nearly three-quarters of the resource-challenged population of the country (AfDB, 2011). However, the contribution of the agricultural sector to economic growth and sustained rural development remains to be fully exploited, while the majority of the population remain vulnerable to food insecurity and poverty. The Nigerian agricultural sector suffers from unreliable transport, storage, marketing and pricing policies, as well as inconsistent agricultural policies at both the local and national government levels. In terms of transport, the roads and rail laid in the 1960s and 1970s in an effort to improve rural communities have either disappeared or are in a dilapidated condition due to lack of maintenance (Agboola, 2000; Apata, Folayan, Apata, \& Akinlua, 2011).

Agriculture is crucial for the development in sub-Saharan Africa, because 70 percent of the population is involved in agriculture (Apata e al., 2011). In many sub-Saharan Africa countries, growing the agricultural sector remains the most effective strategy for reducing poverty and promoting overall economic growth (Diao, Hazell, Resnick, \& Thurlow, 2007). However, subsistence agriculture, which provides and contributes to economic growth and poverty reduction in rural areas of Nigeria, has not been prominent on the national development agenda (Onakuse \& Lenihan, 2008). A report from New Partnership for Africa's Development (NEPAD) (2003) stressed that agriculture-led development is fundamental to reducing hunger and poverty and generating economic growth, as well as decreasing the burden of food imports. The report also noted that it can increase exports, thereby earning much-needed foreign income for the nation. Finally recognizing the potential role of subsistence agricultural development, the government of Nigeria's strategic plan, Vision 2020, ${ }^{1}$ aims to increase agricultural growth by direct investment and increase budgetary allocation to the sector.

The major challenges to sustaining rural agriculture are the use of inappropriate but traditional farming tools (such as cutlasses and hoes), the lack of finances to procure agricultural inputs, and lack of education on modern agricultural practices and postharvest losses (Apata et al., 2011; Collier, 2008). But Bryceson (2000) included other chal-

\footnotetext{
1 The Nigeria Vision 2020 economic transformation blueprint is a 10 -year plan for stimulating Nigeria's economic growth and launching the country onto a path of sustained and rapid economic growth to become one of the world's top 20 economies by 2020. The vision is anchored to the Nigerian Economic Empowerment and Development Strategy (NEEDS II) and its seven-point agenda.
} 
lenges which are specific to subsistence farming, which includes low output, low produce quality, no value addition, lack of storage facilities, lack of access to extension services, production bias, and a poor approach to agriculture modernization. Cultivable land is a crucial input factor for agriculture. According to the National Bureau of Statistics (2011), only 32 million hectares (79 million acres) of arable land is presently under cultivation in Nigeria. Seventy percent of rural residents are active farmers engaged in crop production, which accounts for 85 percent of total agricultural production; livestock accounts for 10 percent, with the remaining 5 percent comes from fisheries and forestry (AfDB, 2011; Rondon, \& Nzeka, 2011).

Some schools of thought suggest that replacing family farming with larger and more diversified farming systems could enhance efficiency and sustainability. However, the present efforts to modernize agriculture have been met with many hurdles, such as a lack of funding, technological changes, education, and the impact of climate change. These lead to a lack of policy focus on increasing food production to alleviate poverty. Reports from the European Union common agricultural policy reforms in 2010 are based on the "Communication on the Common Agricultural Policy" (CAP) toward 2020, which outlined broad policy goals to respond to future challenges for agriculture in rural areas and to meet the CAP objectives. These policy goals include (1) viable food production; (2) sustainable management of natural resources and climate action; and (3) balanced territorial development. The reform orientations in the communication have since been broadly supported both in the interinstitutional debate and in the stakeholder consultation that took place in the framework of the impact assessment at the European Union.

Agricultural growth and increases in farm productivity are prerequisites to broad-based, sustained food security for economic growth and development (Diao et al., 2007; International Bank for Reconstruction and Development \& World Bank, 2007; United Nations Food and Agriculture Organization [FAO], 2002). However, subsistence farmers do not invest in their own farms due to a lack of specific rural agricultural development initiatives. Rather, subsistence farmers constantly organize their production around their family interests in the areas of forestry, livestock, and fishing. It is clear that rural farmers in Uzanu engage in agriculture purely as personal survival strategies rather than as a calculated effort to increase output and generate income.

The goal of a subsistence farmer is not simply to maximize productivity, but to optimize it across far more complex production systems that combine indigenous knowledge and traditional practices. Efficient production emphasizes improved land management and conservation of soil through community-based approaches based on common resources within the community. Community efforts in managing outputs are based on balancing cropping patterns and productive potential to ensure long-term sustainability of current subsistence production levels (IFAD, 2011). Studies based on empirical evidence indicate three main reasons why subsistence agriculture in rural communities (such as that of Uzanu) will continue to survive, although at small scale. First, the lack of proper marketing intelligence and infrastructure are major problems, often deterring farmers from expanding their operations to a commercial scale (Agboola, 2000). Second, increased land scarcity and flooding are major driving forces behind the lack of evolution from subsistence agricultural systems to more intensive production. Third, farmers largely are unaware of the agricultural policies of the government that are supposed to provide strategies to transition traditional agricultural practices to modern forms of agricultural production (Bryceson, 2000; United Nations Development Programme [UNDP], 2000).

\section{Methodology}

Uzanu is characterized by a tropical climate dominated by high temperatures, high humidity, and heavy rainfall. The community experiences two distinct seasons: the wet season (March to November) and dry season (November to February). Uzanu has a humid ( $>0.65 \mathrm{p} /$ pet) climate with an average annual rainfall ranging from $1,500 \mathrm{~mm}$ to $3,000 \mathrm{~mm}$ (59 inches to 118 inches). The temperature averages about $25^{\circ} \mathrm{C}$ $\left(77^{\circ} \mathrm{F}\right)$ in the rainy season and about $28^{\circ} \mathrm{C}\left(82^{\circ} \mathrm{F}\right)$ 
in the dry season. The soil is loamy in nature and characteristics, which is considered ideal for agricultural uses. Loamy soil is composed of sand, silt, and clay in relatively even concentrations and generally contains more nutrients and humus than sandy soils, with better drainage and filtration.

This study encompassed both qualitative and quantitative traits. It sought to document, evaluate, and gain insight into subsistence farming currently and its future, and the livelihoods of the agrarian community where agriculture and allied activities are the major source of family income.

Data relating to the activities of the production system of subsistence farmers in Uzanu were generated through a field survey and analyzed using SPSS version 20. Rural household heads were selected as the sampling unit. A purposive selection technique was used to access a particular subset of farmers actively practicing subsistence farming. One hundred and forty (140) farmers were identified as practicing subsistence farming, out of which 100 responded to the survey. These questionnaires were pretested through a pilot survey to establish and examine key subsistence farmers. The semistructured questionnaires asked questions related to farmers' incomes, farm size, production techniques, harvesting systems, utilization of farm produce, and the roles of family members in agricultural operations. There was no discrimination based on gender or age as the sample size represented almost the entire population of the community.

The survey was conducted between July 2010 and July 2011. The period coincides with both early and late planting seasons. A total of 100 questionnaires were completed through the help of trained enumerators. Trained research assistants helped illiterate heads of households to complete the questionnaires and also addressed any issues that were raised.

\section{Results and Discussion}

\section{The Existing Farm Situation}

Analysis of the existing subsistence rural farm situation in Uzanu focused on production patterns, resource use, and productivity, with the main goal of evaluating the performance for the future of subsistence farming. The study examined farmers' land holdings, yield, and available resources that produced subsistence levels of agricultural production. In spite of the small size of holdings, no farmer was found to be landless in Uzanu. The average land holding of the sample of farmers in Uzanu was 3.6 ha (8.9 acres) per farmer. Eightythree men (83) and seventeen (17) women participated in the survey. Subsistence farmers in the community are older than the population as a whole. Among the study participants, those aged under 30 years were 4.9 percent, those aged 31 to 40 were 24 percent, those aged 41 to 50 were 37.6 percent, those aged 51 to 60 were 27.5 percent, and those aged 61 to 70 were 5.7 percent. The respondents said that the decline in participation in subsistence agriculture among the younger generation is due to their traveling out of the community to acquire modern education outside the community, and to their search for off-farm employment in urban areas.

Farmers in Uzanu cultivate biennial and perennial crops such as cassava (Manihot esculenta), maize (Zea mays), rice (Oryza sativa), and tomatoes (Lycopersicum esculenus), as well as vegetables such as spinach (Spinacia oleracea), amaranth (Amarantbus tricolor), Alefo (Celosia spicata), and fluted pumpkin (Telfairia occidentalis), which are used either as a source of additional food or income for the family. The vegetables represent a small proportion of crops grown, as they are usually intercropped. Citrus trees such as sweet orange (Citrus sinensis) are planted along the farm boundaries, serving both for consumption locally and land demarcation. The average cultivated area per family is about 0.6 hectare ( 1.5 acres) whereas the national averages are classified as follows: Small-scale farms range from 0.10 to 5.99 hectares ( 0.25 to 14.8 acres), medium scale from 6.0 to 9.99 hectares (14.8 to 24.7 acres) and large scale are 10 hectares and above (24.7 acres) (AfDB, 2011). With the practice of shifting cultivation, mixed farming, and intercropping systems, the average output is low due to lack of access to improved pre- and postplanting operations, such as improved land preparation, seeds and seedlings, fertilizer, and plant protection measures. Also, the additional labor required during postplanting operations such 
Photo 1. Rain Water Storage Facility in Uzanu

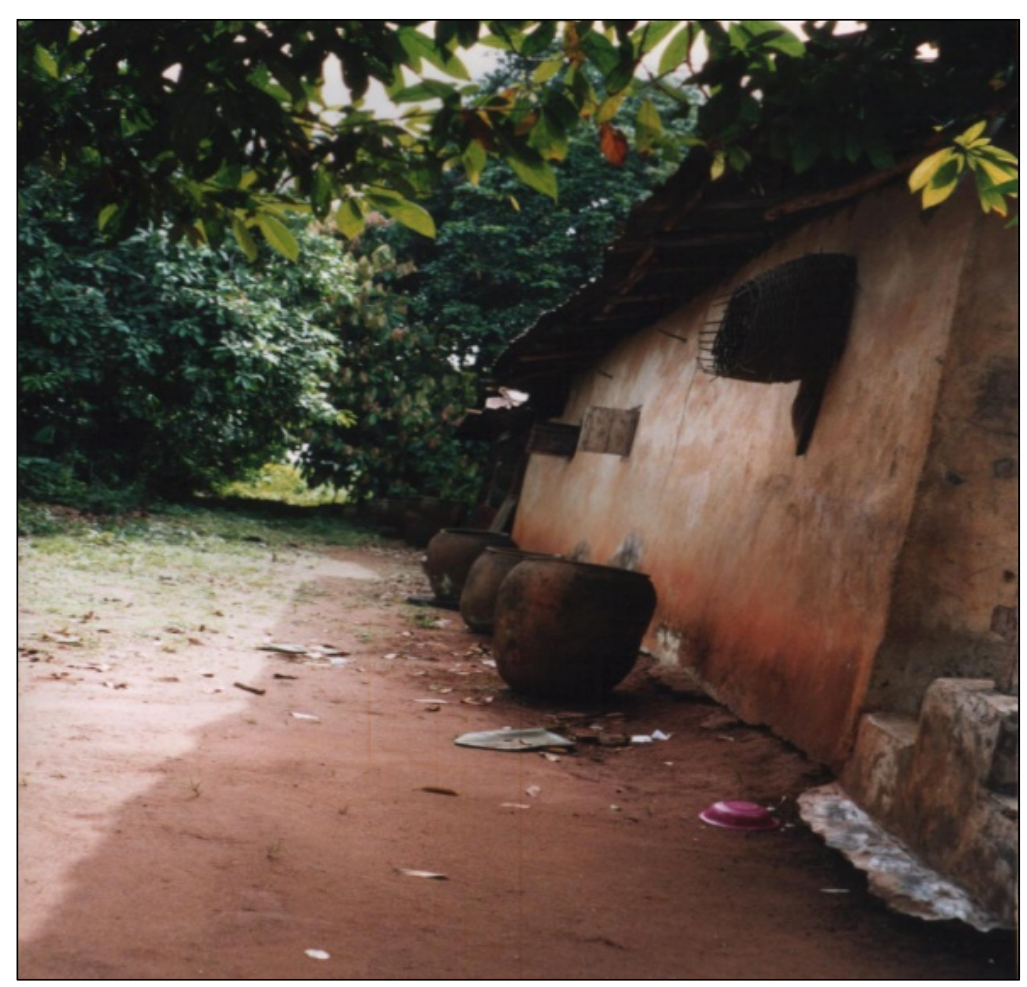

Source: Stephen Onakuse, 2010.

as weeding is not readily available, and so family labor plays an important role. In terms of income, the maximum income is generated by farms with large families and diversified cropping patterns, indicating that the larger the family, the more land is cultivated and the greater output is generated. But the income usually is not enough for large families, and it is usually distributed based on the urgency of need.

The gender distribution shows that 89.2 percent of the respondents were male. All of the female respondents (10.8 percent of the sample) were widows. As far as education, the data analysis indicates that the largest proportion of respondents (42 percent) had no formal education, while 10 percent had completed their secondary education. It may be inferred that the literacy levels among farmers in the area was very low and this may affect the adoption of new farming methods. The majority of farmers had more than 30 years' subsistence farming experience within the community. The distribution by age of the respondents ranged from 4.9 percent who are 30 or less years old; 24.3 percent who are aged 31 to $40 ; 37.6$ percent who are 41 to $50 ; 27.5$ percent who are 51 to 60 ; and 5.7 percent who are 61 to 70 . The overall average household size in Nigeria is 5.82 (AfDB, 2011), but poor rural households in Uzanu tend to be larger, with an average household size of 8.0.

The community has no access to safe drinking water; the only source of drinking water is a stream called Edigah that provides water for both for drinking and domestic use. Rain water is also collected and stored in earthen pots that usually lie outside houses. Due to poor sanitary systems across the community, anecdotal evidence shows that most children in the community suffer from waterborne diseases like trachoma and scabies.

\section{Existing Production Patterns}

The subsistence farmers in Uzanu are engaged in traditional farming, which has remained more or less untouched by modern methods. Due to high levels of illiteracy, most farmers are unaware of alternative methods for agricultural production.

On average, perennial and biennial crops cover 67 percent of the land cultivated yearly, and cassava covers nearly 80 percent of the land under cultivation. Cassava (local cultivars and a mix of IITA hybrid TMS 30555) is the stable food, which is processed into Garri, Fufu (a product locally processed through fermentation for local consumption), pounded cassava, starch (a product from fermented cassava, prepared wet), and is roasted and unprocessed. Cassava has the ability to grow on marginal land where cereals and other crops do not grow well; it can tolerate drought and can grow in low-nutrient soils. Traditionally, only women are involved in the harvesting and processing of staple foods in the village. Table 1 shows the actual average production (in kilograms/ha and pounds/ acre), household consumption and product sold (in percentages). Average output per hectare at subsistence level is lower when compared with 
Table 1. Average Production in Kilograms per Hectare and Acre, and Percentage of Consumption and Sales $(\mathbf{N}=\mathbf{1 0 0})$

\begin{tabular}{lcccc}
\hline Major activity - Crops & $\begin{array}{c}\text { Average output } \\
\text { (kg/ha) }\end{array}$ & $\begin{array}{c}\text { Average output } \\
\text { (pounds/acre) }\end{array}$ & $\begin{array}{c}\text { Household } \\
\text { consumption (\%) }\end{array}$ & Percentage sold \\
\hline Cassava & 4,050 & 3,617 & $67.5 \%$ & $32.5 \%$ \\
\hline Sweet Potato & 1,020 & 911 & $30.5 \%$ & $69.5 \%$ \\
\hline Tomatoes & 540 & 482 & $11.1 \%$ & $88.9 \%$ \\
\hline Maize & 270 & 241 & $56.3 \%$ & $43.7 \%$ \\
\hline Vegetablesa & 124 & 111 & $29.5 \%$ & $70.5 \%$ \\
\hline
\end{tabular}

a Vegetables include spinach (Spinacia oleracea), amaranth (Amaranthus tricolor), Alefo (Celosia spicata), and fluted pumpkin (Telfairia occidentalis).

mechanized and improved cultural practices in cassava crop production. For example, world average cassava yield is about $10,000 \mathrm{~kg} / \mathrm{ha}(10$ metric tonne/ha) or 8,930 pounds/acre.

Other annual crops such as rice, sweet potatoes, and tomatoes are also grown widely for limited cash income and as well as personal consumption. These crops are sold exclusively at the local market in Agenebode, situated 8 miles (13 $\mathrm{km}$ ) away from the community. The sale of surplus produce is the main source of cash for the farmers. These products are sold unprocessed since the farmers have no means to add value and thus to increase prices. Production of these crops depends on how flooding affects land fertility after the rainy season (Onakuse \& Lenihan, 2008). Subsistence farmers in Uzanu generate relatively low incomes after harvesting because of the higher perishability of tomatoes and potatoes compared to other crops, such as rice (which itself requires high labor for planting and weeding).

Although rice has lower perishability, it tends to be low-yielding, which leads farmers to not produce it. In addition, rice production suffers from additional challenges, enumerated by respondents as those involving pests (e.g., weaver birds), rodents (e.g., rats, grass cutters, etc.), and diseases (e.g., rice blast, rice smut, narrow brown leaf spot, leaf blight, etc.).

Sweet potato is another crop that generates cash income for farmers. It is cultivated twice a year, planted first in March and again in July or August. A small amount of cash income is gained during these two periods. Other crops, such as vegetables, which are not sold but are consumed by the household, are cultivated on the same land. Cassava and sweet potatoes are consumed to increase the energy intake of the family. In interviews, farmers recognized that low soil fertility and the pattern of planting small-scale crops are responsible for the low yield of their traditional farming system.

More than 90 percent of surveyed farmers were involved in intercropping and mixed agriculture, together with raising of livestock (goats, sheep, and chicken), which provide an important source of meat (protein) and manure. These livestock are kept mainly for consumption or for immediate sale during times of severe shortage. The livestock is kept close to the household and fed mainly with byproducts of cassava, sweet potatoes, and maize.

Consumption drives the interest in subsistence farming system in rural villages. However, there is no reliable, official statistical information gathered across the country to show patterns in terms of the volume of production at subsistence levels in different communities. For example, 65 percent of the respondents who practice mixed cropping have reduced the cultivation of crops such as tomatoes and potatoes because of the lack of market opportunities and the high perishability of products. But they continue to cultivate these same crops because they see no alternative and the crops are easy to grow and resilient under the region's climatic conditions.

Our study data indicates that both men and women practice mixed farming. However, the 
traditional gender division of labor remains operational in all the surveyed households. The preplanting operation such as clearing, which requires heavy physical work, is carried out by men; the women respondents hire laborers to do this work. The planting of root crops is a joint activity, although in many places yams are strictly cultivated by men. After planting, the subsequent agronomic tasks are the responsibility of the men. For cultural reasons, women sell the various farm surpluses and use the resulting income to buy essential commodities such as cloth, salt, medicines, kerosene, cutlasses, and hoes, while the surplus income is used to support other household needs as well as children's education. The farmers rely mostly on seeds saved from the previous season, so generally do not have the expense of purchasing seed.

\section{Household Income of Subsistence Farmers}

Table 2 shows actual net average household income of survey respondents over five seasons (2006 to 2010). Given the focus of this research on the future of subsistence agriculture for the rural livelihoods of Uzanu residents, the income is based on subsistence farming only, and excludes any offfarm income. There are no industries in the community that provide off-farm employment opportunities, although households participate in other off-farm activities that provide additional income such collecting firewood and forest fruits. However, most farmers indicated that they receive remittances from their children who have migrated to the cities; this supplements their income but is not included in table 2 .

The distribution of income among households who participated in the survey showed that their incomes tend to vary due to differences in the amount of land they cultivate and the availability of family labor during pre- and postplanting operations. This is a common practice among subsistence farmers who plant less with limited land and who have little or no means to hire extra labor (Baiphethi \& Jacobs, 2009).
Table 2. Total of Household Income over a Five-Year Recall Period, 2006-2010, by Seasonal Planting $(\mathrm{N}=100)$

\begin{tabular}{rrrr} 
Year & $\begin{array}{c}\text { Total Household } \\
\text { Income }\end{array}$ & $\begin{array}{c}\text { First Planting } \\
\text { (\% of total) }\end{array}$ & $\begin{array}{c}\text { Second Planting } \\
\text { (\% of total) }\end{array}$ \\
\hline 2006 & $\$ 16.66$ & $\$ 5.83(35 \%)$ & $\$ 10.83(65 \%)$ \\
\hline 2007 & 17.77 & $6.06(34 \%)$ & $11.70(66 \%)$ \\
\hline 2008 & 9.24 & $4.22(45 \%)$ & $5.02(55 \%)$ \\
\hline 009 & 33.33 & $10.00(30 \%)$ & $23.33(70 \%)$ \\
\hline otal & 26.66 & $8.96(33 \%)$ & $17.70(67 \%)$ \\
\hline
\end{tabular}

Note: The exchange rate between U.S. dollars and Nigeria naira is USD1 = N150. ource: July 2010-July 2011, Survey 2011.

It can be observed from table 2 that income levels differ between the two planting times - first and second seasonal planting. When compared to the national average wage income per annum in Nigeria, these earnings are low. The low income earning are indicative of the characteristics of subsistence rural farming in the Uzanu community. Subsistence production as practiced by the respondents was not valued at market prices but by its contribution to the household food safety net. Despite the critical importance of subsistence production for household food security of Uzanu farmers, a majority of the households' income as shown in table 2 are below the poverty line.

Most interviewed farmers attributed their low income to postharvest loss. There was a consensus among the respondents that a large percentage of the harvest was left to rot due to lack of storage facilities and conservation methods, and few or no market outlets at which to sell the products.

Farmers are prevented from accessing high market prices in the agricultural commodity chain because of the lack of skills and means for processing and packaging.

The general income from subsistence production is low, likely due to factors such as low capital input into production, low level of education, and the low prices received for farm products. The interviewed farmers revealed that they had no access to loans, and this also accounts for the subsistence nature of the farm holdings. 
Table 3. Land Holdings and Cropping Patterns of Households (Acres) $(\mathrm{N}=100)$

\begin{tabular}{llll}
\hline Description & Mean & SD & t-value \\
\hline Cultivated area & 1.43 & 0.74 & $3.521 * * *$ \\
\hline Cassava tubers & 1.30 & 0.62 & $2.331 * *$ \\
\hline Rice & 0.33 & 0.14 & 0.233 \\
\hline Potatoes & 0.32 & 0.20 & $2.365 * *$ \\
\hline Maize & 0.19 & 0.08 & 0.011 \\
\hline
\end{tabular}

$* * *(P<0.01) * *(P<0.05)$

These factors stand as major constraints to agricultural development.

The relationship between land size and income could not be measured over time as some of the farms surveyed were too small to do more in-depth analysis. The farmers, however, strongly agreed with the notion that land holding is directly related to income. Additional factors such as the availability of family labor, and age and gender of the farmer, are significant to both farm output and income.

Most farms in our study are small in size and scattered because they practice shifting cultivation (see table 3). The farmers indicated that they owned their own piece of farmland. All the farmers interviewed indicated that the main reason for practicing shifting cultivation was to allow for soil rejuvenation over a three-year period, depending on whether the land was needed by particular farmer. The farmers also indicated that depending on farm inputs and rainfall patterns, the production from their farms was sufficient to meet home consumption needs and would like to be able to sell instead of having it rot.

As a farmer revealed during an interview,

We would prefer to remain small-scale farmers and become successful, growing quality products for sale and consumption and being able to build a decent house on our land. We seek to live a descent lifestyle, equal to my counterparts in the cities, while remaining on our land in the village. (Field interview, 2011)
Agricultural development relies on linkages and networks. All the farmers interviewed said that they had never had any contact with an external agricultural extension agent, and that extension services were not available in the study area. This lack of contact results in the farmers' exclusion from direct extension services as well as from extension services that link farmers to research institutions such as the International Institute of Tropical Agriculture and other service providers. These institutions could help to improve subsistence agricultural activities in rural areas.

\section{Conclusions and Recommendations}

This study shows that subsistence agriculture is an important part of rural livelihoods in Nigeria. Subsistence agriculture contributes not just to the agricultural development of rural communities, but to Nigeria as a whole. Therefore, sustainable agriculture requires tackling the numerous problems that militate against subsistence agriculture in rural communities. This suggests that it is important to focus on developing interventions that would have a positive impact on subsistence agricultural practices. These interventions might work to rejuvenate subsistence agricultural practices through education, agricultural research, and microcredit; to reduce postharvest loss; to develop markets; and even to provide subsidies directly to farmers.

Subsistence agriculture remains the major contributor to the growth and development of the rural economy. Even though subsistence agriculture is declining in rural areas as youth migrate to urban centers for white-collar jobs, both federal and state governments should develop contextspecific programs targeted at improving subsistence agriculture and its contribution to livelihood security in rural communities such as Uzanu. The policy focus should be on advancing subsistence farming methods while reducing the risks associated with postharvest losses. Furthermore, specific policies need to be directed at creating access to markets and technical means for food processing. This will enhance the capacity and sustainability necessary to increase subsistence farming improvements over the long term. 
In addition, policies that encompass a clear vision of sustainable farming activities can increase the efficiency of subsistence agricultural practices in rural areas. To achieve this, subsistence farmers would need to work together as cooperatives, community-based organizations, and household production units in order to access farm inputs at affordable prices, and also to provide an outlet for the sale of goods produced as a group.

\section{Bibliography}

Agboola, A. A. (2000). Farming systems in Nigeria. In M. O. Akoroda (Ed.), Agronomy in Nigeria (pp. 2534). Ibadan, Nigeria: University of Ibadan Press.

African Development Bank Group [AfDB]. (2011). African economic outlook: Nigeria 2011. Abidjan, Ivory Coast: AfDB, OECD, UNDP, UNECA. Retrieved from http://www.afdb.org/fileadmin/uploads/ afdb/Documents/Publications/Nigeria $\% 20$ Full $\%$ 20PDF $\% 20$ Country $\% 20$ Note 01.pdf

Apata, T. G., Folayan, A., Apata, O. M., \& Akinlua, J. (2011, April). The economic role of Nigeria's subsistence agriculture in the transition process: Implications for rural development. Paper presented at the annual conference of the Agricultural Economics Society, Warwick University, Coventry, UK.

Baiphethi, M. N., \& Jacobs, P. T. (2009). The contribution of subsistence farming to food security in South Africa. Agrekon, 48(4), 459-482. http://dx.doi.org/10.1080/03031853.2009.9523836

Bryceson, D. (2000). Rural Africa at the crossroads: Livelihood practices and policies. Natural Resource Perspectives, 52. London: Overseas Development Institute.

Collier, P. (2008). The politics of hunger: How illusion and greed fan the food crisis. Foreign Affairs, November/December. Retrieved from http://www.foreignaffairs.com/articles/64607/ paul-collier/the-politics-of-hunger

Communication from the Commission to the European Parliament, the Council, the European Economic and Social Committee and the Committee of the Regions The CAP towards 2020: seek to meet the food, natural resources and territorial challenges of the future, $\operatorname{COM}(2010) 672$ final, 18.11.2010.

Diao, X., Hazell, P. B. R., Resnick, D., \& Thurlow, J. (2007). The role of agriculture in development: Implications for sub-Sabaran Africa (Research Report 153).
Washington, D.C.: International Food Policy

Research Institute (IFPRI). http://dx.doi.org/10.2499/9780896291614RR153

FSDH Securities Limited. (2011). Economic \& financial market: Review \& outlook (2011). Lagos, Nigeria: Author. Retrieved from http://www.fsdhsecurities. $\mathrm{com} /$ periodic/Year2011.pdf

Ellis, F. (1993). Peasant economics: Farm households and agrarian development (2nd Ed.). Cambridge: Cambridge University Press.

Heidhues, F., \& Brüntrup, M. (2003). Subsistence agriculture in development: Its role in processes of structural change. In S. Abele \& K. Frohberg (Eds.), Subsistence agriculture in Central and Eastern Europe: How to break the vicious circle? (Volume 22, pp. 1-27). Halle (Saale), Germany: Institut für Agrarentwicklung in Mittel- und Osteuropa (IAMO).

International Bank for Reconstruction and Development \& The World Bank. (2007). World development report 2008: Agriculture for development. Washington, D.C.: The World Bank. Retrieved from http://www.worldbank.org

International Fund for Agricultural Development [IFAD]. (2011). IFAD's Environment and Natural Resource Management Policy: Resilient livelihoods through the sustainable use of natural assets (Report EB 2011/102/R.9). Rome: Author. Retrieved from http://www.ifad.org/gbdocs/eb/102/e/EB-2011102-R-9.pdf

Kostov, P., \& Lingard, J. (2002). Subsistence farming in transitional economies: Lessons from Bulgaria. Journal of Rural Studies, 18(1), 83-94. http://dx.doi.org/10.1016/S0743-0167(01)00026-2

New Partnership for Africa's Development [NEPAD]. (2003, July). Comprehensive Africa Agriculture Development Programme. Midrand, South Africa: New Partnership for Africa's Development

Onakuse, S., \& Lenihan, E. (2008). Rural livelihood insecurity in Edo State: A case study of Etsako East Local Government Area of Nigeria. Journal of Sustainable Development, 5 (1-2), 2-11.

Redman, M. (2010). Securing public benefits from subsistence agriculture in Romania: Assessing the impact of rural development policies (incl. LEADER). Tartu, Estonia: Centre for Ecological Engineering. Retrieved from Rural Development Impacts (RuDI) website: http://www.rudi-europe.net 
Rondon, R., \& Nzeka, U. (2011). Exporter guide for Nigeria. Lagos, Nigeria: USDA Foreign Agricultural Service. Retrieved from http://www.nigerian seminarsandtrainings.com/articles-pdf/Exporter Guide Lagos Nigeria 6-24-2011.pdf

United Nations Development Programme [UNDP]. (2000). Overcoming buman poverty: UNDP Poverty Report 2000. New York: Author.
United Nations Food and Agriculture Organization [FAO]. (2002, February). FAO support to "The New Partnership for Africa's Development": Land and water resources issues and agricultural development (Report from the 22nd Regional Conference for Africa, Cairo). Retrieved from http://www.fao.org 